\title{
Forests at the crossroads: Environmental challenges for Canada in the 21st Century ${ }^{1}$
}

\author{
by John Spears ${ }^{2}$
}

The main theme of this paper that there is already enough knowledge and past experience to confirm that forests could make a major contribution to those sustainable development and environmental challenges of the 21 st century that were outlined by the Brundtland Commission.

However, this is unlikely to happen unless national governments world wide, are prepared to implement several politically difficult reforms. First, of prevailing institutional processes that determine rights to public forest land access and use. Second elimination of perverse economic policies that adversely impact on forests and the environment. Third adoption of strategies that aim to minimise the area of forest devoted to harvesting and manufacture of traditional forest products and to maximise the area in which primary management goals are preservation of local subsistence needs and of environmental and recreational services.

Growing awareness of the implications of forest decline for human welfare and the global environment, imply that in the coming century, ordinary citizens and local communities will increasingly insist on their right to influence decisions on how, and by whom, forests are managed and for whose benefit.

To accommodate those concerns new institutional mechanisms are needed both at the local and global level:

- For decision making on forest land use.

- For independent monitoring of forest resource health and quality.

Key areas of economic reform include:

- Elimination of those forest, agriculture transportation, industrial and other subsidies that are one of the main underlying causes of deforestation and forest decline.

- Introduction of taxation policies that benefit forests and which reflect their environmental values.

The extensive approaches to forest land use, harvesting and manufacture of industrial forest products that have prevailed in the present century, were based mainly on low levels of annual productivity of commercially valuable species and expansion of the forest frontier. These approaches do not satisfy legitimate societal demands for protection of environmental values. Continued adherence to these policies is certain to result in economic dislocation, to collapse of many industrial forest communities and to escalating friction between developmental and conservation interests.

The alternative is to adopt policies that will minimise the land area required to produce industrial forest products needed by society. By increasing the productivity of industrial forests based on already proven sustainable management practices that also protect their environmental services, it would be possible to dedicate a substantial proportion of the world's remaining forests exclusively to meeting the needs of local communities and to preservation of their environmental and recreational benefits.

\footnotetext{
${ }^{1}$ Paper presented to the 90 th Annual General Meeting of the Canadian Institute of Forestry, 4-8 October 1998, Ottawa.

${ }^{2}$ Former Secretary General, World Commission on Forests and Sustainable Development.
}

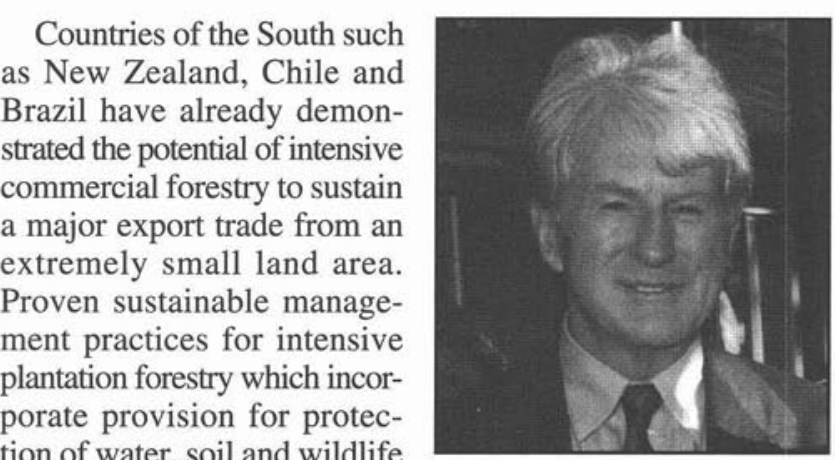
tion of water, soil and wildlife resources are already available. Wood costs from those plantations are less than half of those prevailing in Canada and Scandinavia.

The technology exists both in temperate and tropical regions to produce most of the industrial timber, pulp and paper, that will be required in the 21 st century, from an area equivalent to less than one third of the world's remaining 3.4 billion hectares of forest. Policies are needed that will provide incentives for private sector investment in intensive, sustainable commercial forestry, linked to safeguards that will protect the interests of local communities and the environment.

Without waiting for agreement on a so far elusive Global Forest Convention, governments, private sector industry, and investors in those 12 major forested countries on the North and South that account for about 75 per cent of the world's forest area and forest products output, and of which Canada is one of the largest, could provide much needed collaborative leadership by taking immediate steps to implement the above suggested reforms and forest land use strategies.

\section{Forests at the Crossroads: Environmental Challenges for Canada in the 21st Century}

In the first part of this talk I intend briefly to summarise how our perceptions of the role of forests to contribute to broader goals of environmentally sustainable development as defined by the Brundtland Commission have evolved in the present century. I conclude that on all environmental fronts, enough scientific knowledge and experience already exists to confirm that forests do indeed have the potential to make a major contribution to the environmental challenges of the 21 st century.

This is equally true whether we are talking about preservation of the habitat of forest dependent communities, of biodiversity and genetic resources, the carbon sequestration potential of forests, protection of soil water wildlife and fishery resources, the policies and technologies for ensuring renewable energy and sustainable land use, as well as environmentally sustainable production of traditional forest products.

In the second part of this talk I address the obvious question: if indeed so much knowledge and experience is already available, why is it not being applied.

The constraints are primarily political. They emanate from the sharply contrasting perspectives of different segments of society about how and by whom forests should be managed and 
for whose benefit, and from resistance of vested interests to policy reforms.

The latter part of this paper suggests several key areas of policy reform and a radical change in past forest land use strategies that, if adopted by national governments and private sector industry, would eliminate some of the main underlying causes of conflict between conservation and developmental interests. They would do much to satisfy the aspirations of local communities, of environmentally concerned citizens and of private industry and at the same time ensure that forests contribute to preservation of the the global environment.

\section{The Brundtland Commission}

Just about ten years have elapsed sine the World Commission on Environment and Development (more popularly known as the Brundtland Commission) produced its report "Our Common Future."

That report made a major impact in raising global awareness of the risks, both to people and the planet, of the economic growth policies that had been the dominant objective of the most government development plans since the end of World War II.

The main message of "Our Common Future" was that to continue the pursuit of economic growth without taking into account the regenerative capacity of the earth was a suicidal strategy both for all of us and for the global environment.

The Brundtland Commission, the Secretary General of which was a leading Canadian Development Economist, Jim MacNeill, defined sustainable development as:

\section{"development that meets the needs of the present without compromising the ability of future generations to meet their own needs."}

The Brundtland recommendations were taken seriously by the national government leaders who met in Rio de Janeiro in 1992 at the Earth Summit and who, with guidance from another distinguished Canadian, Maurice Strong, produced UNCED's Agenda 21. This was an ambitious global programme based on the principle that to achieve sustainable development, environmental protection strategies needed to be incorporated as an integral component of all future government development plans.

Agenda 21 included many recommendations that were targeted at sustainable management of the earth's forest resources. Six years later, national government forest policies and resources allocations by development agencies still fall woefully short of the targets set by that programme.

\section{Foresters' Perceptions of Environmentally Sustainable Management}

Foresters are not unfamiliar with the concept of sustainable management. Many of my own generation were brought up on the teachings of famous forest scientists such as Schlich who for the last three hundred years had been preaching and practising their version of sustainable forest management in the forests of Germany, France and other parts of Europe.

We were taught that sustainable management required that forests be harvested and tended in ways that would ensure a continuous flow of timber and that the best way to protect the environmental integrity of forests was by keeping people and livestock out of them. In short, foresters in those days felt somewhat smugly that we were doing a great service to the world by taking a long term view and protecting forests for the benefit of future generations.

However, as I discovered very early on in my own career, those definitions of sustainable forest management were fatally flawed. To illustrate from personal experience, I started my career as an Assistant Conservator of Forests in Kenya in 1952. The day after landing in Nairobi I was posted as a District Forest Officer to manage a quarter million acre forest reserve on the slopes of Mount Elgon on the Kenya/Uganda border.

Eager to put what I had been taught about sustainable forest management into practice, I interpreted that mandate first by making sure that two large sawmills on Mount Elgon that were felling 200 year old Podocarpus trees and hauling out logs five feet in diameter, only removed the mature trees that had been marked for felling.

Second, I made sure that they paid up the $\$ 0.50$ per cubic meter royalty that was the government stumpage rate. (This was for timber that was selling on the lumber markets for $\$ 50$ per cubic meter, i.e., about 100 times greater than the legislated royalty rate!)

Third, as a "conservator" of forests, it was my job at all costs to keep local people and their livestock out of the Mount Elgon forests which had been gazetted as a government forest reserve. It had been made clear that my eligibility for promotion would be partly influenced by my success in collecting fines for illegal forest entry and grazing. This aspect of my duties certainly did not endear me to the local populace. Ever since those days, that experience has made me sympathetic to the unenviable lot of those city parking ticket collectors whose livelihood depends mainly on how many pink stickers they succeed in placing on your car windscreen!

The implicit assumption of Kenya forest policy in those early days was that by setting girth limits for sustainable timber production, this would automatically ensure adequate forest regeneration and protection of forest environmental benefits such as conservation of wildlife and water resources.

By vigorously pursuing forest laws drafted in the early 1900 s that restricted local people's access to government forests, we were acting in their bests interests. Their children would wake up every morning and, as I was able to do from my forest station window, enjoy looking over the garden fence at hundreds of happily grazing buffalo and elephant.

Well, it is hardly surprising that the average Mount Elgon forest fringe farmer struggling to bring up eight children on a 2 acre small holding was not particularly enamoured with these policies! Nor is it surprising that the local populace, being highly aware that the Mount Elgon forest boundary stretched over 150 miles and knowing that it was unlikely that I would be able to visit their particular part of the forest reserve boundary on foot more than once a year, merely moved their stock out of the forest for the two days that I spent in their vicinity and then, after I had moved on, drove them back in again.

\section{Forests and People}

Those earlier "forestocentric" perceptions of my own generation were quickly to be challenged in many parts of the world by representatives of hundreds of forest-dependent communities, who were no longer willing to accept the restrictive forest laws and narrowly focused management systems developed during the colonial era. 
Their aspirations were supported by non-government organisations and by the studies of social scientists and policy researchers such as Michael Arnold who, as far back as the 1960's, initiated many useful pilot scale community forest projects. From these and numerous subsequent studies we have learned much about the high degree of dependence of rural people on forests, how they contribute to sustainable livelihoods, and how local people who are highly aware of the environmental benefits of the forests in which they live have successfully managed them over hundreds of years.

For example, we now know that in the forests of the Amazon and Congo basins as well as in the forests of Indonesia and other parts of South East Asia, indigenous tribal communities totalling some 60 million people world wide, obtain almost all of their subsistence, food, clothing and other needs from the forest whilst preserving the forests in an intact and healthy state. The work of Don Gilmour in Nepal, and numerous studies by Gil Shepherd, Mark Poffenberger and others have documented how local village communities have successfully managed forest resources in an environmentally sustainable way based on traditional knowledge.

Here in North America, a recent IUCN review of community forest experiences includes examples of successful local management of forests by, for example, the Cree of Waswanipi in northern Quebec, the Meadow Lake Tribal Council of Saskatchewan, and the Menominee tribe in Wisconsin who have been sustainably managing some 230000 acres of forest land for commercial timber production for over 150 years. An independent evaluation of their forests concluded that their forest preservation and management practices have not only benefited wildlife, streams and biodiversity but also produced a steadily expanding output of commercial forest products.

In short, evidence such as the above suggests that forests can be managed for sustainable timber production whilst at the same time protecting local people's interests and forest environmental benefits.

In the context of a developing country preserving the environmental benefits of forests is inextricably linked to food security, to essential nutrition and medicinal needs, to income generation, and to poverty alleviation. Based on recognition of these linkages, leading world foresters such as Jack Westoby of FAO, who had visited China and India and who understood the shortcomings of earlier industrial forest paradigms, were instrumental in insisting as far back as 1978 that the World Forest Congress held that year in Indonesia took as its main theme "Forests for People."

\section{Forests and Water Resources}

Also back in the $1950 \mathrm{~s}$ and $60 \mathrm{~s}$, foresters began to focus on improved scientific understanding of the ways in which forest land settlement schemes and different types of forest land use in the tropics were likely to influence water resources.

There were launched in East Africa, by Saskatchewanborn Charles Pereira and his colleagues, a number of scientific hydrological studies aimed at improved understanding of the role that forests and other types of land use play in regulating water supply and minimising soil erosion.

Based on some 15 years of continuous monitoring and subsequent similar studies carried on by Larry Hamilton and others working at the East West Centre in Hawaii, today we have a fairly clear understanding of how changes from forest to other forms of land use are likely to affect stream flow and down stream sedimentation. Useful analytical tools for economic evaluation of the relationship between upland forests and downstream benefits were developed by Hans Gregersen from the University of Minnesota, among others.

The importance of this topic can be judged from a recent statement from Canada's Forest Ministers which observed that Canada's forests, which account for 10 per cent of the world forest area, play an important role in protecting 20 per cent of the world forest area, play an important role in protecting 20 per cent of the world's fresh water.

\section{Forests and Energy Supply}

During the 1970s the oil crisis triggered much research into improved understanding of the ways in which forests contribute to global energy supply and into the technical possibilities and likely economic viability of renewable biomassbased fuels. The Shell International Petroleum Company, for whom I worked for a short period, recognized the inevitability of oil price rises in the 21 st century, and began to invest heavily in forest plantations in countries such as New Zealand and Chile. The rationale was initially to supply traditional forest industries, but with the longer term possibility of production of biomass fuels. A recent Shell Company review of changing energy patterns in the 21st century forecasts a very significant increase in dependency on renewable sources of energy, particularly those that are solar, wind, and biomass-based.

\section{Agroforestry and Sustainable Land Use}

Another notable development of the 1970s initiated by Canadian John Bene with the support of Canada's International Development Research Centre (IDRC) was establishment in Nairobi of the International Centre for Research on Agroforestry. Since then, ICRAF has done much scientifically to document how farm trees and remnant woodlands contribute to soil fertility, to increased crop production, to agricultural sustainability, and to carbon sequestration. Based on this evidence, agencies such as the World Bank began to invest heavily in socially-oriented agroforestry programmes in India and many other countries.

\section{Forests, Biodiversity and Genetic Resources}

During the 1980s, as environmental awareness of the costs to society and the planet of forest degradation increased, we learned much about the role that forests play in contributing to preservation of biodiversity and genetic resources. Leading world scientists such as Professor E.O. Wilson alerted us to the fact that forests provide habitat for at least two thirds of the world's plant and animal species.

They concluded that we are already amid a species extinction crisis unmatched in the last 65 million years and that, given current deforestation trends, one quarter of the world's species may disappear by the middle of the next century. Many species being lost are not even known to science, let alone studied for their useful properties.

Imminently threatened forest plant species include, for example, the wild germ plasm of key crops such as rubber and arabica coffee. As I once observed at an international forest conference in Bellagio held some 20 years ago and chaired by a Canadian former Vice President of the World Bank, David Hopper, a world without condoms and coffee would be in pretty poor shape! 
Of equal concern would be the loss of hundreds of forest plants from which are derived about a quarter of the medicines which you find on the shelves of your local drug store. It was Norman Myers who pointed out that from the rosy periwinkle, a forest plant from Madagascar, is extracted one of the most effective drugs for treating leukemia.

Based on growing world concerns about the loss of species, the convention on Biodiversity drafted during the Earth Summit and ratified in 1992, has provided an umbrella for international action to set aside and protect a substantial part of the word's forests as biodiversity reserves.

\section{Forests and Global Climate}

Also during the 1980s and continuing into the 1990s, we began better to understand how forests regulate both local and global climate. Based on studies carried out by George Woodwell and his colleagues at the Woods Hole Research Centre in Massachusetts and here in Canada by Michael Apps of the Canadian Forest Service and many others, we have learned that forest burning contributes about $20-25$ per cent of those greenhouse gases that are responsible for global warming.

On the other side of the coin, forests are a major carbon store. By sequestering atmospheric carbon they play a pivotal role in stabilising the earth's climate and slowing global warming. The climatic consequences of forest loss have, therefore, today become a matter of increasing international concern.

The Framework Convention on Climate Change provides the beginnings of a legislative basis for national and global action.

\section{Forests and Recreation}

For many urban people living in industrialised countries, where they often account for more than 90 per cent of the population, the most highly valued benefit of forests is the recreational opportunities they provide and the possibility to escape from the pressures of city living. Forest and wildlife-based ecotourism is a major source of revenue in several countries. For example, a recent WorldWatch paper noted that although US National Forests are currently managed primarily for timber and that logging adds 76000 jobs and $\$ 3.5$ billion to GDP, recreational use of national forests generates some 2.6 million jobs and adds about $\$ 98$ billion to GDP.

As Andrew Bennet, U.K.'s Under Secretary of Natural Resources, observed during a lecture given at Kew Gardens last year:

"In many parts of the world in the coming century, ordinary families hiking or taking their dog for a walk in the forest will have more of an influence on how forests are managed than the managers of large timber companies."

\section{Urban Forestry}

Urban forestry, which was almost unheard of in the 1950s, now appears as a significant item in the annual budget of many city councils. Urban parks and protected trees make a vast improvement to city environments and to the quality of life of the almost half the world's population who live in them.

\section{Valuation of Forest Environmental Benefits}

Based on preliminary research by David Pearce and his colleagues at the London-based Centre for Social and Economic Research on the Global Environment (CSERGE), there is a growing body of evidence that in many situations the collec-

\begin{tabular}{lcc}
\hline \multicolumn{3}{l}{ Table 1. Valuing forest environmental benefits (US\$ per hectare) } \\
\hline & Costa Rica & Pininsular Malaysia \\
\hline Timber & 1240 & 1024 \\
Non-timber products & n.a. & $96-487$ \\
Carbon storage & 3046 & 2449 \\
Pharmaceuticals & 2 & $1-103$ \\
Ecotourism/recreation & 209 & $13-35$ \\
Watershed protection & n.a. & n.a. \\
\hline
\end{tabular}

Source: BluePrint for Capturing Global Environmental Values: David Pearce (1995).

tive value of environmental benefits and services provided by forests such as those briefly summarised above may significantly exceed timber values. See, for example, Table 1 which sets out preliminary findings from ongoing research in Costa Rica and Peninsular Malaysia.

Ongoing studies suggest that in many situations, carbon storage is likely to be the most significant of all environmental benefits. It is this emerging conclusion that is providing the basis for experimental financial deals such as the ongoing carbon trades between North and South which provide a market-based financial mechanism through which some developing countries are receiving payments for the carbon sequestration value of their forests that are of greater global than local benefit.

\section{The Role of Research}

Accumulation of the knowledge that has been gained over the last 30 years of how forests work, the value of the numerous environmental goods and services they provide, and of the many ways in which they are already contributing to sustainable development reflects will on the past investment made in both scientific and socio-economic policy research. It highlights the importance of continued and expanded support for research and development and the valuable contributions now being made by the member institutions of International Union of Forest Research Organizations (IUFRO) and Consultative Group on International Agricultural Research (CGIAR) institutions such as Centre for International Forestry Research (CIFOR) and (ICRAF).

\section{Constraints to Progress}

Given the extent of scientific knowledge and past experience of how to manage forests in an environmentally sustainable way one could be tempted to draw the comforting conclusion that all is well and that without any need to tinker with global forest policies we can rest assured that forests will make a decisive contribution to the environmental challenges of the 21st century. Regrettably, that is not the case.

\section{Global Forest Decline}

Despite the considerable investment in research, much improved knowledge of how forests work, and the many billions of dollars invested by governments, private industry and by the development agencies in forests over the last 30 years, the environmental situation both on the ground and in the earth's atmosphere has precipitously gone from bad to worse.

During this same period, the world's forests have declined both in area and quality. Some 200 million hectares of tropical forest disappeared between 1980 and 1985. Whilst part of that constituted a logical conversion from forests situated on 
fertile soils and flat land to sustainable agriculture, much of it occurred in fragile upland watersheds of South East Asia, and in the rainforests of the tropics. Those forests overlie acidic soils of low potential and which, once the forest has gone, revert to low grade pastures or scrub.

Nor has deforestation been confined to the tropics. Studies by Sten Nillson and his colleagues from the International Institute for Applied Systems Analysis and by the World Bank reported recently that large areas of forest in Siberia that were clear felled in the 1970 s have failed to regenerate.

Substantial deterioration in the health and quality of temperate zone forests has also been observed. For example, a European Forest Institute study concluded that more than a quarter of European forests surveyed were being defoliated and weakened by a combination of industrial and traffic pollution, drought and inappropriate past silvicultural practices.

If we take a look ahead to the 21 st century, all the signals point to increasing pressure on forests and the risk of even stronger conflicts between conservation and developmental interests. In short, the challenge will be how to slow forest decline whilst simultaneously trying to meet the essential food, energy, timber, water supply requirements, economic growth expectations, recreational and other forest-related needs of a world of about 10 billion people (roughly double that of 1990).

Many of those additional people will be living in rural poverty or overcrowded cities, trying to survive in a changing global climate that during this last year alone, has spawned more tornadoes and forest fires than ever before in recorded history.

Today over 1 billion people in developing countries live on less than a dollar a day. Even the most optimistic assumptions about economic growth make it difficult to avoid the unpalatable conclusion that for countries such as Rwanda, Burundi and large parts of India, there will remain a massive number of small farmers or landless people who will need to be fed, housed, and maintained, many of whom will remain vitally dependent on forests.

The UN projects that the number of people living in cities, which has increased more than three fold in the last decade and which today accounts for 46 per cent of the global total, could well rise to 80 per cent by the middle of the next century. The challenges that this will present in terms of the need for clean water, sewage and other infrastructure facilities will place an enormous logistical and financial burden on municipal authorities and also on forest resources.

\section{Industrial Forestry}

The present century has witnessed a huge increase in the consumption of timber, wood-based panels and pulp and paper. World wide, the production of manufactured forest products now contributes about $\$ 400$ billion to the world economy. Over $\$ 100$ billion worth of forest products are traded internationally and forest-based industries provide employment for some $60 \mathrm{mil}-$ lion people. More than $\$ 30$ billion of forest products are exported from Canada every year.

Since 1960, world paper production has increased three and a half times to today's figure of about 280 million tons and will double again in the next century. According to a report prepared by Professor Solberg and his colleagues from the European Forest Institute, world demands for industrial roundwood, which are currently in the order of 1.7 billion cubic metres a year, will increase to something between 2.5 and 3.0 billion cubic meters a year by 2050 .

Awareness of the threats posed both to local communities and to the global environment by escalating pressures on forest lands for agriculture, mining and oil exploration, increasing demands for forest products and the activities of less responsible forest harvesting and management companies, has already lead to conflict between different interest groups. These conflicts have escalated sharply in recent years and in some situations have lead to violent and life-threatening confrontations.

At the heart of these conflicts lie increasing demands for timber, the commercial profits that can be realised from forest products manufacture, the pressures that are being brought to bear on local politicians to exploit forests or forest lands as a quick way to create jobs and/or, particularly in developing countries, to generate development revenues. These problems are exacerbated by the wasteful consumption patterns of more affluent societies. Increasing confrontation between commercial and environmental interests in the coming century is inevitable unless there is a very significant change of direction in global forest land use strategy.

In short, those responsible for setting forest policies for the 21 st century find themselves at a crossroads. Adherence to the central government and industry-dominated forest policies of the past is a blind alley which can only lead to further social and economic disruption, confrontation and environmental degradation. The way ahead lies with politically difficult institutional and economic reforms that will accommodate the reasonable aspirations of all societal groups and ensure preservation of those social and ecological services provided by forests that are crucial both to human welfare and to the global environment.

\section{Global Responses}

To address rising global awareness of these disturbing trends, an Intergovernmental Panel on Forests, the Secretariat of which was headed by a leading Canadian forester, Jag Maini, was established three years ago. The IPF, as it was known, conducted a series of intergovernmental workshops on difficult policy issues and presented its report to the UN General Assembly in August of last year.

Also established at about the same time was an independent World Commission on Forests and Sustainable Development (WCFSD) comprised of a group of 25 eminent political leaders and scientists with whom I had the priviledge of working for two years. The report of the Commission, "Our Forests: Our Future," is about to be published.

These reports cover a wide spectrum of activities (too many in my own judgement!). There is a serious danger, as proved to be the case with Agenda 21 (which contained over 100 recommendations for action on forests), that five years from now many people will be asking as they did at the recent IFF meeting in Geneva, what has all this global debate on forests produced and why is it that so many of the recommendations were never acted upon?

In short, I believe that some prioritisation of global action is a matter of urgency.

\section{Priorities for Global Action}

Many will argue that the first priority is to pursue a Global Forest Convention, an objective with which I do not necessarily 
disagree. However, the past history of negotiations over such Conventions and the unwillingness of some governments to abide by their requirements suggests that it will take much time and patience before international agreement is reached on a Forests Convention and before it could make a positive impact.

In the meantime, I would suggest that there are three areas in which action could be taken tomorrow to slow global forest degradation and to ensure preservation of the environmental services provided by the world's forests. They are:

(a) Institutional reforms that create equal opportunity for all segments of society to be involved in decision-making on forest land use and in the monitoring of forest operations worldwide.

(b) Economic reforms that eliminate those perverse subsidies that are one of the main underlying causes of deforestation and forest loss and support for taxation policies that benefit forests.

(c) Commitment of national governments to minimise the area of forest land devoted to commercial forestry and to maximise the area set aside for protection of environmental and other benefits.

\section{Institutional Reforms}

A first step towards reconciliation of conflicting societal demands would be unconditional acceptance by all national governments of the principle of participatory forest land use planning. More democratic institutional mechanisms are needed at both national and global levels that will create partnerships between local communities, industry, and governments based on mutually-agreed management objectives.

In the coming century it is certain that ordinary citizens and local communities will increasingly insist on their right to participate in decision-making about how forests are managed and for whose benefit. This situation argues for swift government action to accommodate those demands.

Some of the best examples of such participatory institutional arrangements come from India, where something between 10000 and 15000 communities have entered into joint management partnerships with state governments. A national forest policy act of 1988 explicitly recognised the legal status of joint management contracts.

Here in Canada, the British Columbia experience offers much hope that workable arrangements for participatory land use planning can rapidly be put in place provided provincial Governments have the political will to do so. For example, the recent Vanderhoof Land and Resource Management Plan was developed through a two and a half year consensus-building process among groups representing a wide spectrum of public interests. They included water, fisheries, heritage, culture, recreation, tourism, wildlife, agriculture, mining, timber and conservation.

One of the submissions presented to the World Commission was an analysis of the Clayoquot Sound experience where there was created a Central Regional Board (CRB) to review and agree upon forest conservation and development plants.

To quote from a submission the Commission received from Elizabeth May, Executive Director of the Sierra Club:

"Membership of the CRB is equally divided between members appointed by the Province and those appointed by First Nations. As all decisions must be made by consensus the First Nations have in essence secured their right to veto."
A commendable feature of the Clayoquot Sound debate was the establishment of an independent scientific panel to oversee the proposals for sustainable management. To quote Dr. Fred Bunnell, the Chair of that panel:

"The underlying precautionary principle of management recommended for the Sound has virtually turned traditional forest practice on its head. The Panel has recommended that rather than deciding what industry wanted to take out of the forest, logging decisions should be based on what ideally should remain."

Similar participatory planning approaches are being tested in other provinces and under Canada's promising Model Forest programme.

In short, Canada is well placed to provide global leadership in this area. As Assistant Deputy Minister Dr. Yvan Hardy stated in a recent interview:

"In the past we (in Canada) used forests to create capital for infrastructure development. Now we need to know people's new expectations and how to conciliate those many different forces, whether communities, non-governmental organisations, or the global community."

\section{Global Institutions}

Despite the intensity of the international debate conducted by the IPF and WCFSD over the last two years and creation of the Intergovernmental Forest Forum, current governance mechanisms for forests at the international level continue to reflect many of those same weaknesses that were spelled out by CIF President Ralph Roberts in the papers that he and George Nagle presented to the last two World Forest Congress meetings. In those papers they argue convincingly for a world forest body that would include equitable representation of all different interest groups.

Several alternative options for achieving that objective are discussed in a recent paper prepared by Mike Apsey for the Canadian Forest Service. They range from a strengthening of UN agency and CSD forest negotiating bodies to the establishment of an independent Global Forest Council as recommended by the World Commission.

Whichever of those options (or others) the global community decides to pursue, the key point about all of the options in Mike Apsey's paper is that they recognise the importance of creating opportunity for local community, non-government organisations and private sector industrial interests to be involved $a s$ equal partners in determining global forest policies and in monitoring of global forest change.

As was the case for Clayoquot Sound, decision-making by such a more democratic global body would be facilitated by the parallel creation of a Global Forest Scientific Council that would address issues such as the global environmental implications of alternative forest land use policies.

\section{Institutional Arrangements for Independent Monitoring of Forest Industrial Operations}

The recent emergence of citizen-driven movements such as the Forest Stewardship Council (FSC) and Global Forest Watch are another expression of the growing insistence of ordinary citizens to be involved in decision-making, in independent assessment of how public forests are to be logged and managed and how forest benefits should be distributed. 
Recognition of the inevitability of this trend is implicit in the recent decision of the World Bank and World Wildlife Fund to join forces in a campaign aimed at increasing the world's protected areas and achieving a target of 200 million hectares of independently certified, sustainably managed forests by the year 2005.

The principles and criteria for responsible forest stewardship by the FSC are similar in many respects to those being pursued by some of the world's more responsible forest corporations. It is my personal view that many transnational companies have little to fear and much to gain by accepting the principles of transparency and independent certification. Large reputable corporations such as Assi Doman in Sweden, Collins Pine in the USA and MacMillan Bloedel recently here in Canada have either already accepted or, as in the case of MacMillan Bloedel, are seriously considering. FSC certification and it seems likely that others will follow suit. What are needed are mechanisms for rewarding those companies that adopt such principles and codes of conduct.

Conversely, much tougher mechanisms are needed for penalising those less responsible companies that adopt inappropriate practices and engage in corruption. For example, a report by Nigel Sizer of the World Resources Institute noted that in 1994 the European Union fined 40 major pulp and paperproducing companies for corrupt practices.

A recent study by Indonesia's Forest Service estimated that the government has been losing more than $\$ 3$ billion a year in revenues because of illegal logging. In the 1980s the Philippines lost about $\$ 1.8$ billion a year from illegal logging. In Ghana, 11 foreign companies (mainly from Europe) were implicated in fraud and other malpractices costing the economy about $\$ 50$ million.

Non-government Organisations such as Transparency International, the Environmental Investigation Agency, Global Witness and the "Green Scissors" Movement in the USA, all have a role to play in this area. A recent example of how ordinary citizens have been able to influence matters comes from Papua New Guinea, where forest villagers sued an Australian multinational for destruction of the fish and other resources in a $200 \mathrm{~km}$ stretch of river. The company was forced to pay $\$ 90$ million to local communities in compensation.

\section{Economic Policy Reforms}

Two areas of economic policy reform that would have an immediate and positive influence on forests and the environment are elimination of those perverse subsidies that are one of the major underlying causes of forest degradation and introduction of taxation policies that favour forest conservation.

\section{Perverse Subsidies}

A report for the Earth Council prepared by André de Moor from the Netherlands and Peter Calamai, a Canadian journalist, highlights the types of subsidy that act against sustainable development and contribute to environmental degradation. They estimated that, worldwide, subsidies in only four sectors, (agriculture, energy, road transport and water), add up to at least $\$ 700$ billion a year.

A similar global review of forest sector-related subsidies is currently in progress. However, without waiting for the outcome, there is already enough well documented evidence to confirm that agriculture, transportation, and forest industry subsidies negatively affect forests in a major way either by offering incentives for deforestation or by encouraging harvesting well above sustainable levels of allowable cut.

To cite just a few examples:

- In the USA, 117 out of 122 national forests returned less money to the treasury in 1995 than the forest service spent on preparing these concessions for sale. Between 1992 and 1994, the government's timber sales programme lost $\$ 1$ billion in direct costs alone.

- In Brazil, cattle ranching subsidies were a major driving force behind deforestation of the Amazon rain forests. The desirability of their elimination was thoroughly analysed and publicised as far back as the mid-1970s.

- In France, unutilised forest lands are taxed at higher rates than agricultural incomes, which are either taxed at very low rates or not at all. This policy, which has been maintained for two centuries, has encouraged conversion of forest land despite the fact that much of this former forest land is unsuitable for sustainable agriculture.

- In the Solomons Islands, landowners were paid \$2.70 per cubic meter for timber that foreign companies then sold for $\$ 350$ per cubic meter.

To quote Jeff Vincent of the Harvard Institute for International development:

"Timber producing countries often complain that they cannot afford the additional costs for programmes required to monitor and protect forests and promote their sustainable management. But if those same governments captured the full market value of timber concession through stumpage fees, they would have sufficient resources to enforce logging regulations fully and to administer programmes to address other causes of deforestation."

Even though the impact of such perverse subsidies on forests has been thoroughly researched and many recommendations made in the past for their elimination, a combination of vested interests and lack of political will have consistently blocked attempts to remove them. Yet there is compelling evidence that removal of such subsidies can have an almost immediate and positive impact on forests and on the global environment.

To cite just one example, in 1995 the Russian government took a decision to drastically cut rail transportation subsidies. The effect was to reduce the economic haulage radius of logging by some 3000 kilometres. Logging operations in large areas of forest are no longer commercially viable and, as they close down, those forests that were formerly under exploitation will in future be protected and managed for their environmental and recreational benefits.

\section{Taxation Policies that Benefit Forests and the Environment}

Since 1991 six national governments in Europe have made small cuts in conventional taxes on income and raised taxes on activities that cause environmental harm. As one illustration of the potential benefit to forests, in Sweden a tax on industrial sulphur dioxide emissions (which are the main cause of the country's severe acid rain problem) made a significant contribution to a 40 per cent decline in sulphur emissions achieved between 1985 and 1995.

A recent innovative tax development in Brazil has been the introduction of ecological value added taxes in the states of Parana 


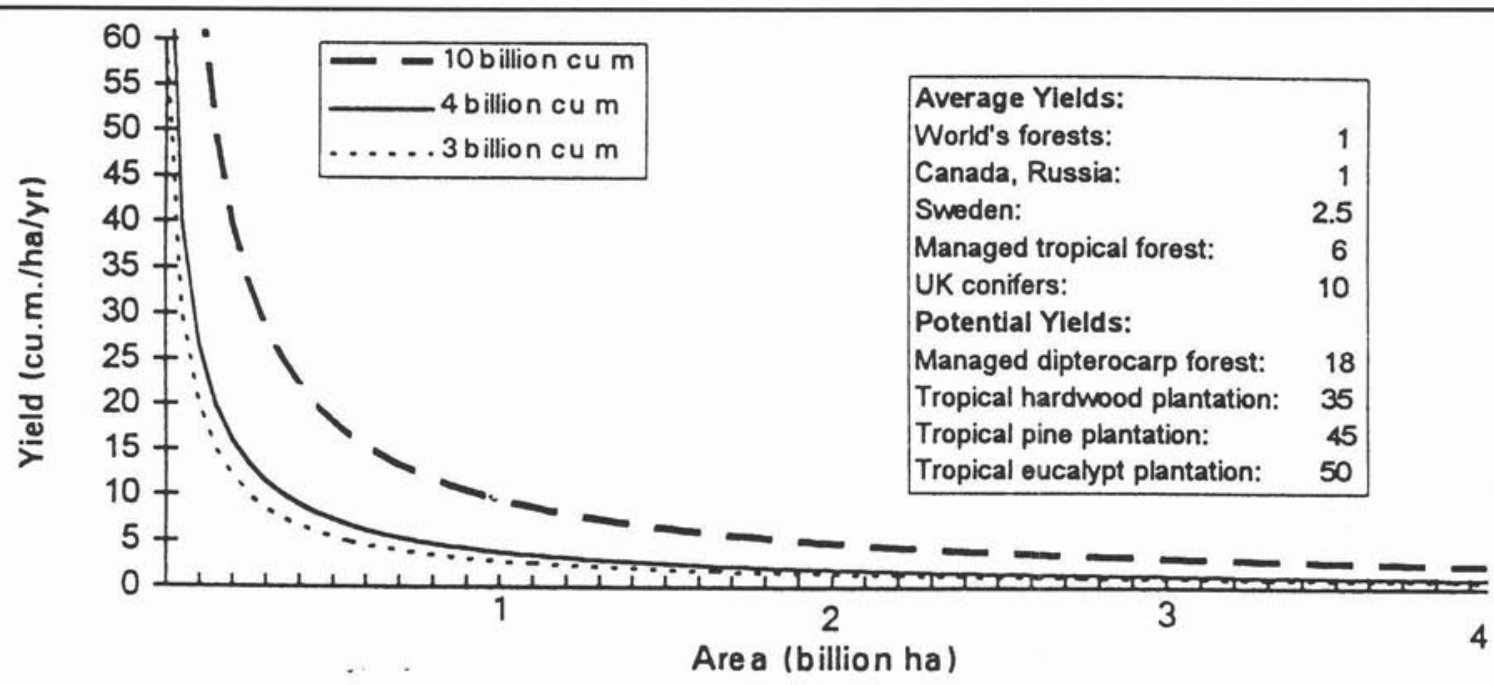

Source: Paper presented by D. Poore to Science, Forests and Sustainability: A Policy Dialogue. CIFOR and the Government of Indonesia, December 1994.

Fig. 1. Impact of productivity increases on the area of forest required to produce the world's timber supply.

and Minas Gerias. Municipalities in the state of Parana which protected forested watersheds to secure clean drinking water supplies and those which set aside large areas of forest as private or public national parks asked the state for compensation for their activities. Municipalities with protected areas have benefited from this value added tax and achieved significant increases in revenue.

\section{Minimising the Area of Global Forests under Commercial Management}

A recent study of long term forest trends in British Columbia concluded that a combination of increased wood costs, declining availability of old growth timber, competition from lower cost industrial wood producers and increased demand for the environmental services of forests, could result in a 23 per cent reduction in total harvest, the loss of over 90,000 jobs and nearly a $\$ 5$ billion reduction in the GDP of the Province.

A similar pattern of extensive exploitation followed by the collapse of many logging communities has already occurred in several tropical countries such as Nigeria, Thailand and Philippines which were formerly large scale exporters of forest products but are now importing on a massive scale. This despite the fact that they have large areas of forest land and a favourable climate for growing highly productive commercial forests.

In the coming century, three world trends will have a major impact on Canadian forest policies and practices and also on current forest land use and industrial development strategies worldwide. First, by the middle of next century more than half of the world's industrial wood demand will be for pulp and paper. Second, the costs of producing cellulose fibre in the southern States of the USA and countries such as new Zealand, Chile and Brazil will remain less than half of those currently prevailing in Canada and Scandinavia. The comparative economic advantage that such countries have in mass production of pulp fibre make it inevitable that they will capture an increasing share of world markets at the expense of higher cost northern producers.
Third, with rising per capita incomes and increasing public awareness of what is at stake if forests are mismanaged, citizen pressures for setting aside larger areas of forest for protection of their environmental and recreational benefits will continue to escalate. These trends argue for minimising the area of commercial forest by increasing productivity and maximising the area of forest to be preserved for environmental and recreational benefits.

The evidence that such a strategy is achievable is already available. Calculations of allowable cut in the present century have typically been based on yields of between 1 and 3 cubic meters of commercially harvestable wood per hectare, compared with a potential productivity of 10 cubic meters per year from intensively managed temperate forests and 40 cubic meters or more for countries of the southern hemisphere.

Yields of these orders of magnitude have already been realised in more intensively managed temperate forests such as parts of Vancouver Island, the U.K., and in the southern hemisphere in the plantations of New Zealand, Chile and Brazil, South Africa and parts of India and China. Duncan Poore's graph below illustrates the global implications of this experience for forest strategy in the 21 st century.

The figure illustrates the area that would be required to produce specified quantities of timber for each level of productivity. Average annual timber productivity worldwide is currently 1 cubic meter per hectare per year. Thus, the 3.4 billion hectares of remaining closed forest of the world could theoretically produce the 3 billion cubic meters of industrial wood needed by the middle of the next century but only if every hectare of forest was brought under commercial production.

At the other extreme only 100 million hectares of tropical plantation (i.e., only 3 per cent of the world's forest area) could hypothetically generate the same volume of timber harvest. Several trans- national corporations have already recognized the comparative economic advantage of tropical plantation-based bulk cellulose fibre production. Perhaps the most successful of these is the ARACRUZ eucalyptus-based hardwood pulp operation in Brazil where a combination of tree breeding and 
improvement have average raised productivity of its 150,000 hectares of plantations from 24 cubic meters in 1987 to 45 cubic meters per year in 1997. Based on this small area of forest, Brazil has become the sixth largest exporter of hardwood pulp within a period of 20 years.

Other corporations such as Fletcher Challenge and the Shell International Petroleum Company are rapidly expanding their plantation resources in Latin America and elsewhere in the tropics. In the USA the trend is towards relocation of industry in the more productive forest areas of the southern states.

It would clearly be unrealistic to postulate a 21 st century world that depends for all of its industrial fibre supply on plantations grown in the southern hemisphere. However, what is a practical possibility is production of all the industrial fibre needed in the coming century from a combination of southern hemisphere plantations occupying an extremely small proportion of land (preferably abandoned agricultural land or heavily degraded forest), plus a continuing supply of industrial forest products derived from a concentrated area of highly productive commercial forests in the temperate and boreal regions.

The net effect of this strategy would be that two thirds or more of the 3.4 billion hectares of remaining global forest could be permanently protected and managed for the benefit of local communities and for preservation of their local and global environmental and recreational benefits. Let me illustrate this point with two examples, one from the tropics and the other from here in Canada.

Reverting to personal experience, when I commenced by forest career in Kenya in the 1950s almost 100 per cent of the commercially harvested timber was being produced by logging old growth in the natural forests that covered Mount Kenya, the Aberdares, the Mau and Elgeyo escarpments and Mount Elgon. Extensive timber concessions had been allocated covering a very large proportion of those forests, the annual allowable cut calculations for which were based on 1 cubic meter of commercially extractable wood per hectare per year.

Government policy aimed to supplement those timber supplies with fast growing plantations of cypress and pines. By the mid 1960s when I left Kenya about 80000 hectares acres of such plantations had been established. Average mean annual increments ranged from 15 to 25 cubic meters per hectare. Harvesting costs were so much lower in those plantations and the demands for construction grade timber and paper were rising so rapidly that almost without coercion, the timber industry relocated to these new plantation areas. They abandoned the bulldozer-based harvesting systems that had been needed to extract logs from the natural forest and adopted rubber-tired plantation logging machines. Many small scale mills owned by local Kenyan entrepreneurs were awarded licences to operate in plantation forests.

Most sawmillers and the owners of the country's largest pulp mill were quick to recognise that the fast growing softwood plantations to which they now had access were eminently suitable for production of the sort of construction grade lumber and paper products that were needed by Kenya's rapidly expanding populations than to attempt a second round of cutting of the mixed hardwoods that made up the natural forest.

The net result of this policy is that today more than 90 per cent of the commercial timber, plywood and pulp and paper used by Kenya's 27 million people is derived from a relatively small plantation area which is equivalent to less than 10 per cent $\overline{\text { Table 2. Scenario for increasing British Columbia harvests on a reduced }}$ land base

\begin{tabular}{lccc}
\hline Region & Coast & Interior & Total \\
\hline Productive forest land (million ha) & - & - & 51.7 \\
Proposed for timber production (million ha) & 3 & 14 & 17 \\
Current yields $\left(\mathrm{m}^{3} \mathrm{ha}^{-1} \mathrm{yr}^{-1}\right)^{2}$ & $3.0-4.7$ & $1.4-3.7$ & 2.2 \\
Target yields $\left(\mathrm{m}^{3} \mathrm{ha}^{-1} \mathrm{yr}^{-1}\right)^{3}$ & 10 & 5 & 5.9 \\
Potential sustained yield (million $\left.\mathrm{m}^{3} \mathrm{yr}^{-1}\right)$ & 30 & 70 & 100 \\
Area available for parks (million ha) & & & \\
$\quad$ Total & - & - & 73 \\
$\quad$ Productive forest land & - & - & 34.7 \\
\hline
\end{tabular}

Source: ${ }^{1}$ Canadian Council of Forest Ministers (1995). Compendium of Canadian Forestry Statistics, 1994. Ottawa, ON.

${ }^{2}$ Range from BC Ministry of Forests Timber Supply Reviews

${ }^{3}$ Author's estimates. Respectively three and two times current yields, reflecting the greater knowledge of silviculture on the BC Coast. Estimates for both regions are within the current range of yields currently realized within each region.

of the country's 1.1 million hectares of natural forests. All of the remainder are managed either as national parks, water catchment protection areas or Nature Reserves. As in the USA, revenues and employment from forest and wildlifebased ecotourism, far outweigh those of the timber industry.

At the same time the Kenya government has recognised that local forest fringe communities who still depend to a high degree on non-traditional forest products need access to natural forests to collect essential fuelwood and other subsistence needs. The government's forest service is also giving more support for agroforestry on small farms. Whilst there is still a long way to go in terms of meeting local community and farmers' aspirations, there is no question that today Kenya's forest policies are more enlightened that they were in my early days.

The second example is a scenario for increasing Canada's timber harvest on a reduced land base. A 1995 study for the Canadian Council of Forest Ministers suggested that if productivity in commercially designated forests of the B.C. Interior and Coast were raised to between 5 and 10 cubic meters per year it would be possible to increase by ten fold the area of forest land in the province dedicated exclusively to sustaining environmental values that the forest provide. See Table 2.

To quote Clark Binkley (1997):

“...through a policy of zoning and intensive dominant use management, British Columbia could devote about three quarters of the province (an area larger than France) to sustaining non-timber values of the forest."

To summarise, I believe that the supporting evidence already exists for a radical shift from the extensive approaches to commercial forestry that have prevailed throughout the last three centuries to a 21 st century commercial forest policy based on minimisation of commercial area and maximisation of protected forests. What is needed is strong political leadership which puts environmental interests first but which also creates an enabling legislative and incentive framework for encouraging restoration of degraded forests and concentration of private sector funded commercial forestry in a smaller area.

To cite a very recent example of a government that has had the courage to do precisely that I commend you to read an article from the New York Times of September 27th about recent forest land use decisions taken by the government of China. The gist of the article is that, stunned by this summer's devastating floods along the Yangtse river which experts say were inten- 
sified because slopes far up stream had been stripped bare, China has banned cutting in the old growth forests in all the upland watershed of western China. No trees were to be cut after September 1st and all logs must be trucked to timber yards by October 31st. To quote from that article:

"After half a century of rampant clear cutting. China's decision to save the remaining forests along the upper reaches of the Yangtse and other major rivers represents a dramatic shift in priorities in favour of environmental protection. Huge tree planting campaigns have also been promised."

\section{Catering for the Welfare of Logging Communities}

Dramatic shifts in policy such as those recently taken in China have devastating implications for thousands of loggers and their families. For example, in Sichuan Province alone 45000 workers will be laid off. To aid the transition from a logging economy the Central government has committed $\$ 121$ million a year in aid while the province itself will come up with an extra \$24 million to help its western region. A substantial proportion of such funding is earmarked for forest restoration.

The nearest parallel scheme I know of here in Canada is British Columbia's Forest Renewal Programme under which industry and the provincial government jointly contribute funding part of which is earmarked for forest management and to assist in job retraining and incentives for relocation of families who have been adversely affected by precipitate closure of logging operations.

I have not followed the progress made in achieving those objectives but the intent is clearly there. Strong political will is needed to ensure that such funds are in fact channelled to those communities whose lives have been severely disrupted and not siphoned off for other non forest-related needs.

\section{Moving from Recommendations to Action: Opportunities for Global Leadership}

Literally only 12 countries, six in the north and six in the south, account for about 75 per cent of the world's remaining forest and world production of industrial forest products. They are Russia, Canada, the USA, Sweden, Finland, Japan, Brazil, Indonesia, Congo, China, India and Malaysia.

There is a clear opportunity for those countries to play a decisive leadership role in working towards the sort of institutional, economic policy reforms and development strategies that I have outlined in this paper.

Without waiting for the outcome of continuing negotiations over a Forest Convention they could collectively agree to move aggressively to maximise forests that will be preserved to meet local needs and to protect environmental benefits and to reduce the area of forests under commercial management. In this latter area the private sector will have to take a lead role, a fact that some of the world's leading forest corporations have already recognised.
None of the recommendations that I have suggested in this paper will be easy. All of them require extremely difficult political decisions that are likely to be strongly resisted by vested interests both within governments and industry and, in the case of taxation policies and logging communities, by ordinary citizens.

Nevertheless, many forest and forest industry policy leaders in Canada recognise the need for a radical change of direction and are prepared to do so. For example, Canada's recently published "Forest Accord," which reflects the outcome of your 1998 National Forest Congress, included these statements:

"All Canadians are entitled to participate in determining how their forests are used and the purposes for which they are managed" and

"We will fulfil our global responsibilities in the care of use and forests, maintaining their contribution to the environment and the well being of all living things."

The Canadian Institute of Forestry could play a major role in helping to ensure that these commitments are translated into practical action.

If all countries of the world were to adopt and practice those same principles, many of the conflicts that have bedevilled forestry for the last two decades would rapidly become a bad dream and preservation of the global environmental benefits of forests would be assured.

\section{Conclusion}

To summarise, it seems clear from the substantial research effort and experiences of the past that we do know enough about how to manage forests in ways that will ensure that they make a very significant contribution to meeting the sustainable development and environmental challenges of the 21st century.

Given strong global leadership by the 12 major forested countries of the North and South, and particularly by the many farsighted Canadians with whom I have had the good fortune to work over the years, I personally remain optimistic that positive action will be taken. To quote one Dr. LandburghWilson:

"Twixt the Optimist and the Pessimist,

The difference is Droll,

The optimist sees the Doughnut,

And the Pessimist the Hole."

In the years ahead, I intend to keep my eyes on the doughnut. If I end up by having to face an enlarging ozone hole, at least I will be able to do so on a full stomach!

\section{References}

Binkley, C.S. 1997. Preserving nature through intensive plantation forestry: The case for forestland allocation with illustrations from British Columbia. For. Chron. 73(5): 553-559. 